\title{
CO-GASIFICATION OF COAL AND BIOMASS - THERMODYNAMIC AND EXPERIMENTAL STUDY
}

\author{
Akash B. Boharapi ${ }^{1}$, Ganesh R. Kale ${ }^{2}$, Omprakash K. Mahadwad ${ }^{1}$ \\ ${ }^{I}$ Chemical Engg Dept., MGM's Jawaharlal Nehru Engg College, Aurangabad, India \\ ${ }^{2}$ Solid and Hazardous Waste Management Division, CSIR-NEERI, Nagpur, India \\ ${ }^{3}$ Chemical Engg Dept., MGM's Jawaharlal Nehru Engg College, Aurangabad, India
}

\begin{abstract}
Cogasification of coal and biomass is a new area of research. Cogasification offers several advantages than individual feed gasification. A thermodynamic analysis of lignite coal and rice husk cogasification using only steam was studied by using HSC chemistry software in this paper involving the effect of temperature $500-1200^{\circ} \mathrm{C}$ and $\mathrm{GaCR}$ ratio(1-3) on the product gas composition. The study also focused on calculation of thermoneutral conditions and hundred percent carbon conversion temperature in cogasification of lignite coal and rice husk. Experimental study of co gasification of rice husk and coal was also done at fixed steam to carbon ratio. The experimental study was found to be more kinetically controlled.
\end{abstract}

Keyword: cogasification, rice husk, lignite coal, HSC chemistry software, fixed bed.

\section{INTRODUCTION}

The world energy demand is growing due to growth in population and economic development. Advanced and sustainable energy systems and energy saving measures to reduce pollution and greenhouse gas emissions are being researched. Utilization of biomass and coal in advanced power generation systems is being practiced to reduce greenhouse gas emissions. Such systems are receiving more attention due to reduced greenhouse gas emissions and their high power generation efficiency [1]. Coal is one of major source of energy that is available cheaply and hence will continue play a crucial role in the energy demands worldwide. The co-processing of coal and renewable carbon-based biomass makes a clean energy technology rather than using coal alone [2].

Co-gasification of coal and biomass seems to be an attractive technology to produce heat and power, and also to produce liquid and gaseous biofuels using synthesis gas [3]. Gasification technology transforms fossil fuels, such as natural gas, coal, liquid or solid refinery residues, or heavy oils, into synthesis gas, also called syngas, for subsequent utilization as combustible gas using a thermochemical process. This can be extended to use biomass and different kinds of waste as feedstock fuel [4].

Although coal gasification is a well established technology, recently the focus has been shifted to biomass gasification to estimate efficiency and performance of the process [5]. Biomass is a favorable alternative to fossiel fuels as it has comparatively lower negative impact on environment, low nitrogen and sulphur content leading to lower $\mathrm{NO} x$ and $\mathrm{SO}_{2}$ emissions. Use of biomass makes a zero $\mathrm{CO}_{2}$ balance and it can therefore replace conventional fossil fuels in future [6].
Nowadays researchers are interested in co gasification technology and study co gasification of plastic waste with pine-wood, sawdust and coal [7], biomass and petroleum coke with coal [8], coal and wood [3,9], coal and saw dust [10]. It is reported that co-gasification of coal and biomass has some synergy as the process produces a low carbon footprint on the environment and also improves the $\mathrm{H}_{2} / \mathrm{CO}$ ratio in the product gas that is required for liquid fuel synthesis. The inorganic matter present in biomass catalyzes the coal gasification. But co gasification processes require custom fittings and optimized processes for region specific coal and wood residues [5].

Generally co gasification requires steam and air. Rodrigues et al. have evaluated the gasification potential of coal and biomass and also estimated the efficiency by changing operational conditions, related to the gasifying agent (air and steam) [2]. Xie et al. have reported a comprehensive threedimensional numerical model of forestry residue gasification using some critical parameters including temperature, equivalence ratio and steam to biomass ratio and the predicted product gas composition and carbon conversion efficiency were in good agreement with experimental data [11]. Wongsiriamnuay et. al. have experimentally studied the bamboo catalytic gasification in a laboratory-scale, fluidized bed reactor and determined the effects of reactor temperature, gasifying medium, and catalyst to biomass ratio on product gas composition, $\mathrm{H}_{2} / \mathrm{CO}$ ratio, carbon conversion efficiency, heating value, and tar conversion [12]. Rodriguez et. al. have studied the adiabatic gasification model of coffee husk using air steam blends to determine the $\mathrm{CH}$ activation energy $(E)$, effect of equivalence ratio $(\mathrm{ER})$ and steam to fuel ratio $(\mathrm{S}: \mathrm{F})$ on equilibrium temperature and gas composition of $\sim 150$ species [13]. Duan et al. have studied the pressurized turbulent circulating fluidized-bed (CFB) gasification of 
bituminous coal in a lab-scale fluidized-bed gasifier, and reported the effects of the stoichiometric ratio, steam/coal ratio, and preheated temperature of the gasifying agent on coal gasification characteristics [14]. Wang et al. have studied biomass gasification using high-temperature air/steam and have reported its superiority over conventional gasification using low-temperature gases [15]. Lin et. al. have experimentally studied rice husk gasification and pyrolysis in a laboratory-scale fixed-bed reactor to obtain the basic data for process development of rice husk gasification [16].

Use of air in gasification usually results in nitrogen dilution of the gasifier product gas which lowers the value of the produced syngas; making gasification without air/oxygen input beneficial to applications that require syngas input. Thermodynamic studies are the starting points to assess the feasibility of new processes optimum conditions for process development [17]. Some researchers have used HSC chemistry software for coal and biomass gasification processes $[18,19]$.

Coal/biomass gasification involve the many chemical reactions (A1-A9),

$$
\begin{aligned}
& \mathrm{C}+\mathrm{CO}_{2}=2 \mathrm{CO} \\
& \mathrm{C}+\mathrm{H}_{2} \mathrm{O}=\mathrm{CO}+\mathrm{H}_{2} \\
& \mathrm{C}+2 \mathrm{H}_{2}=\mathrm{CH}_{4} \\
& 2 \mathrm{C}+2 \mathrm{H}_{2} \mathrm{O}=\mathrm{CH}_{4}+\mathrm{CO}_{2} \\
& \mathrm{C}+2 \mathrm{H}_{2} \mathrm{O}=2 \mathrm{H}_{2}+\mathrm{CO}_{2} \\
& \mathrm{CH}+\mathrm{H}_{2} \mathrm{O}=\mathrm{CO}+3 \mathrm{H}_{2} \\
& 2 \mathrm{CO}=\mathrm{CO}_{2}+\mathrm{C} \\
& \mathrm{CO}+\mathrm{H}_{2} \mathrm{O}=\mathrm{H}_{2}+\mathrm{CO}_{2}
\end{aligned}
$$

$\mathrm{CH}_{x} \mathrm{O}_{y} \mathrm{~N}_{z} \mathrm{~S}_{s}+\mathrm{H}_{2} \mathrm{O}($ steam $)=\mathrm{CH}_{4}+\mathrm{CO}+\mathrm{H}_{2}+\mathrm{H}_{2} \mathrm{O}$ (unreacted steam $)+\mathrm{C}($ Char $)+\mathrm{Ash}+\mathrm{Tar}$

\section{THERMODYNAMIC STUDY}

\subsection{Methodology}

The procedure used in this study was to extract substitutable gas phase compositions from HSC calculations that were predicted thermodynamically. Initial thermodynamic calculations considered the elements $\mathrm{C}, \mathrm{H}, \mathrm{O}, \mathrm{N}, \mathrm{S}$ and $~ 50$ species, but further simplified systems used only $\mathrm{C}, \mathrm{H}, \mathrm{O}$ bearing species [20]. Thermodynamics provides an extremely powerful method of calculation to study the effects of different process variables on a chemical system at equilibrium state. However, the calculations do not take kinetics into account for this theoretical equilibrium state to be reached. The HSC software was used to make conventional thermodynamic calculations based on the minimization of the free Gibbs energy in order to simulate chemical reaction equilibrium and processes [18].

Although coal and rice husk composition varies a lot, its main constituents are carbon (C), hydrogen and oxygen with negligible amount of sulfur and nitrogen shown in table 1. The composition for 50\% lignite coal and 50\% rice husk (by $\mathrm{wt} \%$ ) is 1 mole of carbon, 0.5901 hydrogen, 0.2208 oxygen, 0.0047 nitrogen and 0.00257 sulfur. This has been used as basis for all calculations in the temperature range of 500$1200^{\circ} \mathrm{C}$ and pressure $1 \mathrm{bar}$ for the entire process study.

Table-1: Ultimate analysis (\% wt) of lignite coal [17] and rice husk [21] by dry ash free basis.

\begin{tabular}{llllll}
\hline & $\mathbf{C}$ & $\mathbf{H}$ & $\mathbf{O}$ & $\mathbf{N}$ & $\mathbf{S}$ \\
\hline Lignite coal & 73.73 & 4.04 & 20.21 & 1.01 & 1.01 \\
Rice husk & 48.7 & 6.9 & 43.98 & 0.36 & - \\
$\begin{array}{l}\text { [50\% lignite } \\
\text { coal \& 50\% } \\
\text { rice husk] }\end{array}$ & 61.21 & 5.47 & 32.05 & 0.68 & 0.505 \\
\hline
\end{tabular}

The species such as $\mathrm{C}(\mathrm{s}), \mathrm{CO}_{2}(\mathrm{~g}), \mathrm{H}_{2}(\mathrm{~g}), \mathrm{CO}(\mathrm{g}), \mathrm{H}_{2} \mathrm{O}(\mathrm{g})$, $\mathrm{CH}_{4}(\mathrm{~g}), \mathrm{H}_{2} \mathrm{~S}(\mathrm{~g}), \mathrm{SO}_{2}(\mathrm{~g}), \mathrm{N}_{2}(\mathrm{~g})$ and $\mathrm{H}_{2} \mathrm{O}$ (l) which are usually found in the cogasification are considered in this study. The gaseous products obtained from HSC calculations were mainly $\mathrm{H}_{2}, \mathrm{CO}_{2}, \mathrm{CO}, \mathrm{CH}_{4}$ and negligible $\mathrm{C} 2+$ hydrocarbons were considered in the calculations similar to the report by some researchers [20]. The input species to the gasifier were carbon (solid), oxygen, hydrogen, sulfur, nitrogen, water and $\mathrm{CO}_{2}$ (in gaseous phase) reacting to give the products. The material balances were done by equilibrium composition module of HSC Chemistry in this study using steam is used as gasifying agent. The GaCR (gasifying agent to carbon ratio) ranged from 1 to 3 . Table 2 shows the cogasification conditions. The effect of variation of feed compositions and temperature on the product formation is discussed in detail in the next section.

Table-2: Cogasification conditions

\begin{tabular}{|l|l|l|l|l|}
\hline $\begin{array}{l}\text { Feed } \\
\text { Condition }\end{array}$ & \multicolumn{2}{|l|}{$\begin{array}{l}\text { Input moles of } \mathbf{C}, \mathbf{H}_{2} \text { \& } \mathbf{O}_{2} \text { in } \\
\text { samples }\end{array}$} & $\begin{array}{l}\mathbf{G a C R} \\
\mathbf{H}_{2} \mathbf{O} / \mathbf{C}\end{array}$ \\
\hline & C & $\mathbf{H}_{2}$ & $\mathbf{O}_{2}$ & \\
\hline A & 1 & 0.5901 & 0.2208 & 1 \\
\hline B & 1 & 0.5901 & 0.2208 & 2 \\
\hline C & 1 & 0.5901 & 0.2208 & 3 \\
\hline
\end{tabular}

\subsection{Results and Discussion}

\subsubsection{Hydrogen Yield}

Hydrogen is desired product in cogasification process for its end use in fuel cells or syngas manufacture. Fig. 1 shows the hydrogen yield in cogasification process at all cases $\mathrm{A}-\mathrm{C}$ in temperature range 500 to $1200^{\circ} \mathrm{C}$ at 1 bar. In steam gasification, the hydrogen yield increased with increase the 
temperature for all cases A-C. It was seen that the hydrogen yield increased upto $\sim 800^{\circ} \mathrm{C}$ and then decreased with increase the temperature. It also observed that increase in $\mathrm{GaCR}$ ratio increased the hydrogen yield.

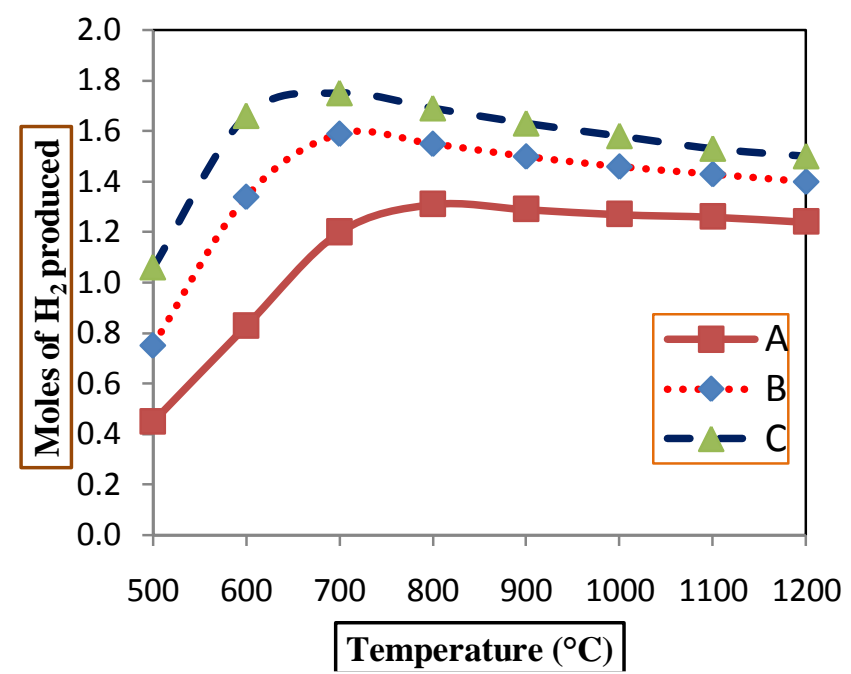

Fig -1: Hydrogen yield in cogasification process.

\subsubsection{Carbon Monoxide (CO) Yield:}

Carbon monoxide is an undesired product in co gasification process. However it is very much desired for syngas feeding applications. Very low $\mathrm{CO}$ levels can be preferentially oxidized to $\mathrm{CO}_{2}$ (PrOx) or converted to methane (methanation). Fig 2 shows the $\mathrm{CO}$ generation trend in the cogasification process at all cases A-C within the temperature range of $500-1200^{\circ} \mathrm{C}$. It was observed that the production of carbon monoxide increased with increase in temperature for all cases A-C. It was also seen that the increase in $\mathrm{GaCR}$ ratio decreased the carbon monoxide yield.

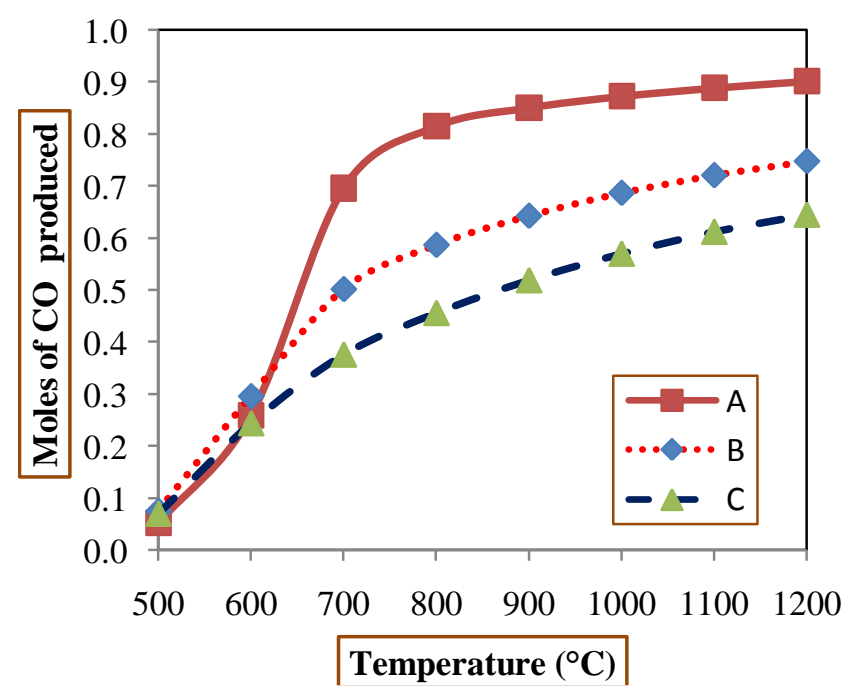

Fig -2: Carbon monoxide yield in cogasification process.

\subsubsection{Syngas Yield}

Syngas yield is sum of hydrogen and carbon monoxide obtained from the process. Syngas is the most desirable product in cogasification of coal and rice husk. Fig 3 shows the syngas yield for all cases A-C within the temperature range $500-1200^{\circ} \mathrm{C}$. In steam cogasification, syngas yield increased with increase the temperature for all cases A-C while it is nearly constant at $\sim 800^{\circ} \mathrm{C}$ for all cases A-C. It also observed that increase the $\mathrm{GaCR}$ ratio increases the syngas yield.

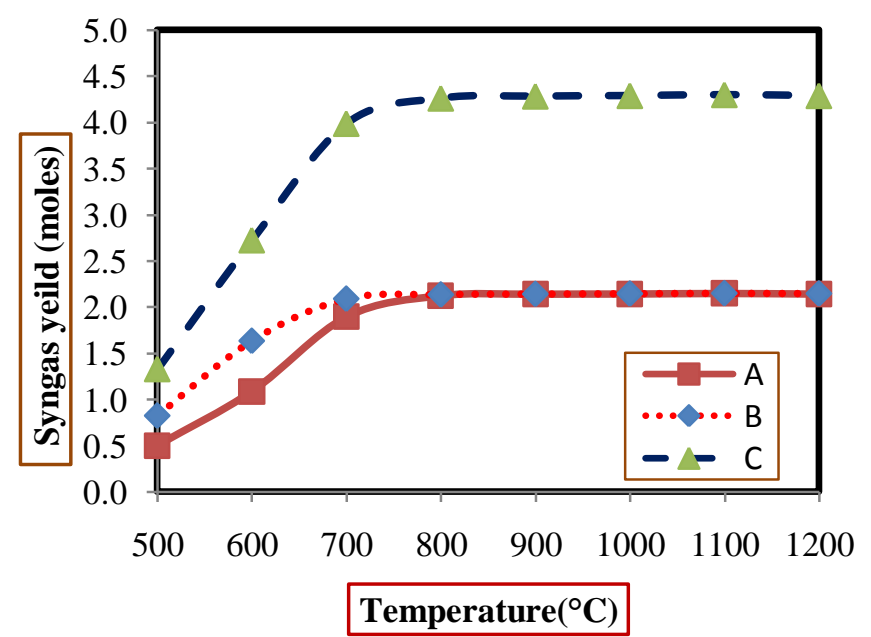

Fig -3: Syngas yield in cogasification process.

\subsubsection{Syngas Ratio}

The syngas ratio $\left(\mathrm{H}_{2} / \mathrm{CO}\right)$ of the product gas obtained in the cogasification process is shown in Fig. 4. It was observed that the syngas ratio decreased with increase the temperature for all cases A-C. It was also observed that increase in $\mathrm{GaCR}$ ratio increased the syngas ratio in all cases.

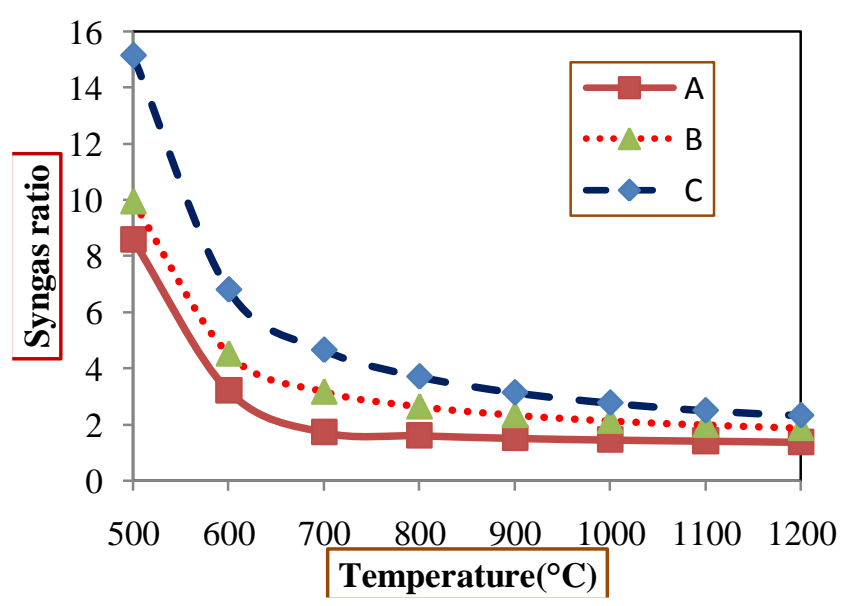

Fig -4: Syngas ratio of product gas

\subsubsection{Methane Formation}

Fig 5 shows the methane formation in cogasification process. It was observed that methane formation generally decreased with increase in temperature from 500 to $1200^{\circ} \mathrm{C}$ at constant GaCR for all cases A-C. Almost zero moles of methane were obtained for all $\mathrm{GaCR}$ conditions in cogasification of lignite coal and rice husk at higher temperatures $>700^{\circ} \mathrm{C}$. 


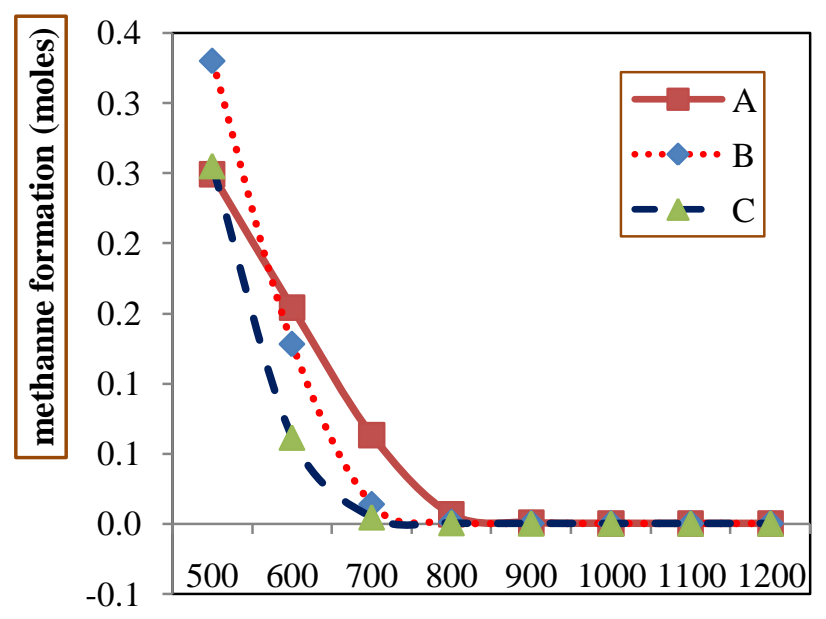

Temperature $\left({ }^{\circ} \mathrm{C}\right)$

Fig -5: $\mathrm{CH}_{4}$ formation in cogasification process.

\subsection{6 $\mathrm{CO}_{2}$ in Product Gas:}

Fig 6 shows the $\mathrm{CO}_{2}$ obtained in the product gas in the lignite coal and rice husk cogasification process. The $\mathrm{CO}_{2}$ generally decreased with increase in temperature from 500 to $1200^{\circ} \mathrm{C}$ at constant $\mathrm{GaCR}$ for all cases $\mathrm{A}-\mathrm{C}$ in cogasification. It was also observed that the $\mathrm{CO}_{2}$ in the product gas increased with increase in GaCR.

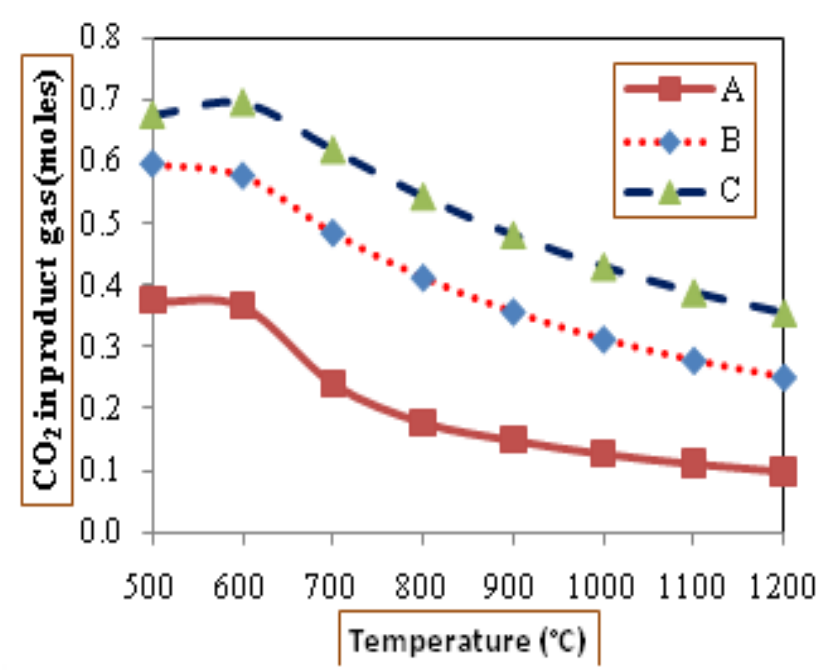

Fig -6: $\mathrm{CO}_{2}$ in product gas in cogasification process.

\subsection{7 $\mathrm{H}_{2} \mathrm{O}$ (g) Conversion (\%):}

Steam plays an important role in production of hydrogen in the steam cogasification process. The excess steam appears in the product gas. Fig. 7 shows the $\mathrm{H}_{2} \mathrm{O}(\mathrm{g})$ conversion $(\%)$ in cogasification process within the temperature range 500$1200^{\circ} \mathrm{C}$ at all cases A-C. It was seen that the steam conversion increased with increase temperature till a particular temperature $\left(\sim 700^{\circ} \mathrm{C}-\right.$ case $\left.\mathrm{A}\right)$ and then decreased with increase the temperature in all cases A-C.

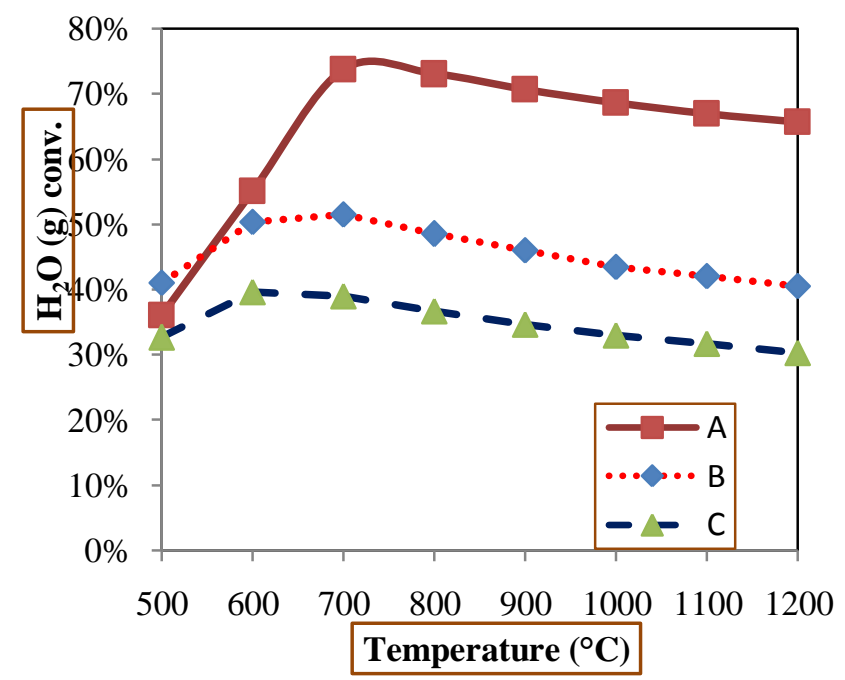

Fig -7: $\mathrm{H}_{2} \mathrm{O}(\mathrm{g})$ conversion $(\%)$ in cogasification process.

\subsubsection{Cogasification Enthalpy and Thermoneutral}

\section{Points:}

Process enthalpy is a crucial parameter in

Cogasification. The effect of gasification temperature on gasification process enthalpy was studied at all feed conditions. The intersection of gasification enthalpy curves with temperature axis shows the thermoneutral temperatures (TNP). Thermoneutral operation requires no external energy for cooling and heating. Fig. 8 shows the variation of gasification enthalpy for lignite coal and rice husk cogasification at constant $\mathrm{GaCR}$ with the thermoneutral line (zero enthalpy line). It was seen that the process enthalpy first increased with increase the temperature and then was almost constant with increase the temperature from 500 to $1200^{\circ} \mathrm{C}$ at constant $\mathrm{GaCR}$ for all cases A-C. Table 3 shows the product gas yield at thermoneutral conditions while table 4 shows the comparison of TNP temperature $\left({ }^{\circ} \mathrm{C}\right)$ and $100 \%$ carbon conversion temperature (HCCT) obtained for different co gasification cases.

Table-3: Product gas composition at thermoneutral temperature $\left({ }^{\circ} \mathrm{C}\right)$.

\begin{tabular}{|c|c|c|c|c|c|c|c|c|c|c|}
\hline $\begin{array}{l}\mathrm{Ca} \\
\text { se }\end{array}$ & $\begin{array}{l}\mathrm{TN} \\
\mathrm{P} \\
\left({ }^{\circ} \mathrm{C}\right. \\
)\end{array}$ & $\begin{array}{l}\mathrm{H}_{2} \\
\mathrm{O} \\
(\mathrm{g} \\
)\end{array}$ & $\begin{array}{l}\mathrm{C} \\
\mathrm{O}_{2} \\
(\mathrm{~g} \\
)\end{array}$ & $\begin{array}{l}\mathrm{H}_{2} \\
(\mathrm{~g} \\
)\end{array}$ & $\begin{array}{l}\mathrm{C} \\
\mathrm{O} \\
(\mathrm{g} \\
)\end{array}$ & $\begin{array}{l}\mathrm{C} \\
\mathrm{H}_{4} \\
(\mathrm{~g} \\
)\end{array}$ & $\begin{array}{l}\text { Syn } \\
\text { gas }\end{array}$ & $\begin{array}{l}\text { Syn } \\
\text { gas } \\
\text { rati } \\
\text { o }\end{array}$ & $\begin{array}{l}\mathrm{H}_{2} \\
\mathrm{O} \\
\mathrm{Co} \\
\mathrm{nv} . \\
(\% \\
)\end{array}$ & $\mathrm{C}$ \\
\hline A & $\begin{array}{l}693 \\
.63\end{array}$ & $\begin{array}{l}0 . \\
26\end{array}$ & $\begin{array}{l}0 . \\
26\end{array}$ & $\begin{array}{l}1 . \\
18\end{array}$ & $\begin{array}{l}0 . \\
68\end{array}$ & $\begin{array}{l}0 . \\
07\end{array}$ & 1.86 & 1.73 & $\begin{array}{l}73 . \\
5\end{array}$ & 0 \\
\hline B & $\begin{array}{l}679 \\
.57\end{array}$ & $\begin{array}{l}0 . \\
96\end{array}$ & $\begin{array}{l}0 . \\
96\end{array}$ & $\begin{array}{l}1 . \\
57\end{array}$ & $\begin{array}{l}0 . \\
47\end{array}$ & $\begin{array}{l}0 . \\
03\end{array}$ & 2.05 & 3.33 & $\begin{array}{l}51 . \\
85\end{array}$ & 0 \\
\hline $\mathrm{C}$ & $\begin{array}{l}683 \\
.56\end{array}$ & $\begin{array}{l}1 . \\
81\end{array}$ & $\begin{array}{l}1 . \\
81\end{array}$ & $\begin{array}{l}1 . \\
75\end{array}$ & $\begin{array}{l}0 . \\
36\end{array}$ & $\begin{array}{l}0 . \\
01\end{array}$ & 2.12 & 4.89 & $\begin{array}{l}39 . \\
4\end{array}$ & 0 \\
\hline
\end{tabular}


Table-4: Comparison between TNP and HCCT

\begin{tabular}{lll}
\hline GaCR & $\begin{array}{l}\text { TNP } \\
\text { temperature } \\
\left({ }^{\circ} \mathbf{C}\right)\end{array}$ & $\begin{array}{l}\mathbf{1 0 0 \%} \text { carbon } \\
\text { conversion } \\
\text { temperature }\end{array}$ \\
\hline $\mathbf{1}$ & 693.63 & $\geq 700$ \\
$\mathbf{2}$ & 679.57 & $\geq 500$ \\
$\mathbf{3}$ & 683.56 & $\geq 500$ \\
\hline
\end{tabular}

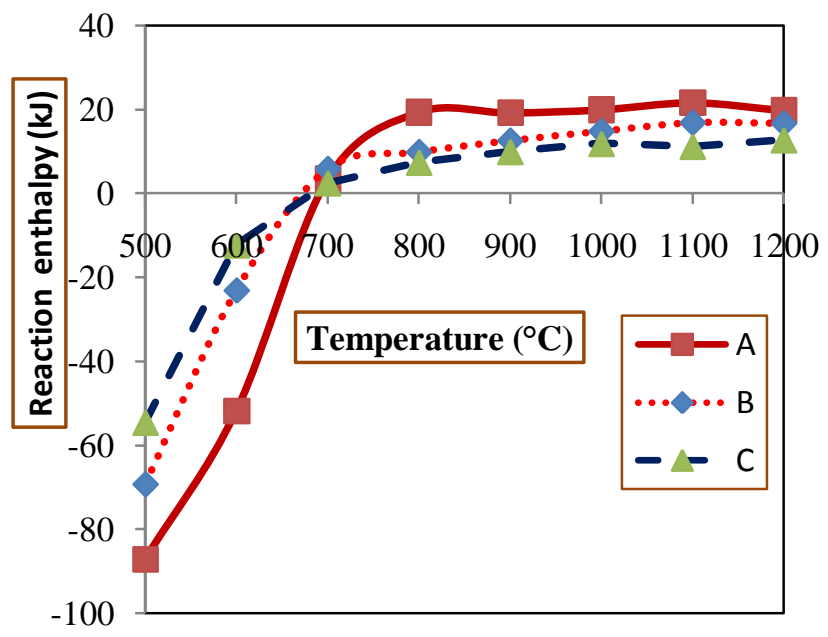

Fig -8: Thermoneutral temperature in cogasification process.

\section{EXPERIMENTAL STUDY}

\subsection{Experimental Setup}

The cogasification of rice husk and coal was studied experimentally. The experimental setup is shown in figure 9. The setup consists of an inconel reactor housed inside a high temperature electrical furnace. Inert silica material is packed in the reactor for uniform heat distribution in the reactor. The reactor ends are insulated using ceramic wool to prevent heat losses from the reactor, which is necessary to maintain constant temperature for the gasification reaction. The product stream passes through a cyclone separator to separate gases and other components. The hot gases are further cooled in the condenser and analyzed using a gas analyzer. The liquid and solid components are collected in the bottom of the cyclone. The calibrated online gas analyzer displays the amount of hydrogen, carbon monoxide and carbon dioxide in the product stream.

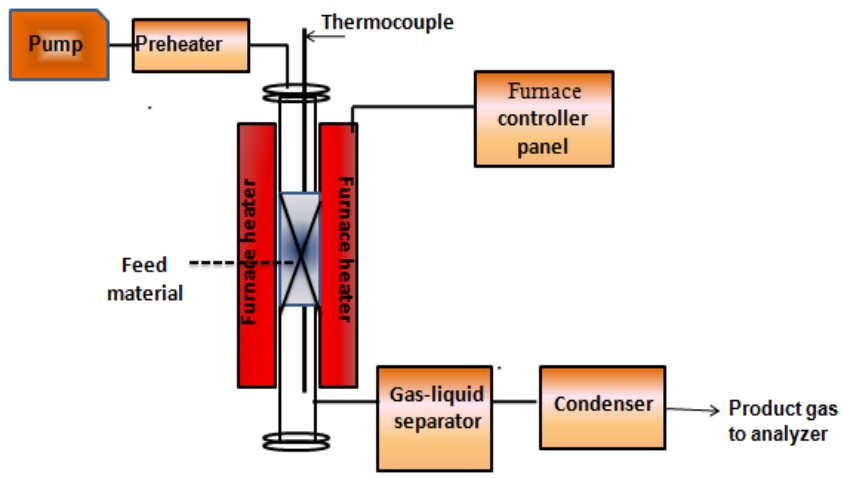

Fig -9: Fixed bed reactor for steam cogasification process.

\subsection{Experimental Procedure}

100 gm crushed homogeneous mixture of coal and rice husk was loaded in the central zone of the reactor. The experiments were performed maintaining constant flow of water. The gasification temperature was varied from 500 to $700^{\circ} \mathrm{C}$. The constant flow rate of steam was introduced into the reactor after $400^{\circ} \mathrm{C}$. The variation in product gas composition with respect to different temperatures was analyzed by online gas analyzer. The variation of various parameters with respect to temperature range is discussed in next section.

\subsection{Result and Discussion}

\subsubsection{Syngas Yield}

The $\%$ yield of syngas was measured by the gas analyzer and is shown in figure 10. It is known that the vol \% is equivalent to mol \% in case of gases. It was seen that the syngas yield generally increased with the increase in temperature and became nearly constant at high temperature. The syngas yield was 56.99 at $600^{\circ} \mathrm{C}$, while at $700^{\circ} \mathrm{C}$ the syngas yield was 75.41 .

\subsubsection{Syngas Ratio}

The $\%$ of hydrogen and carbon monoxide obtained in the gas analyzer used to calculate the syngas ratio $\left(\mathrm{H}_{2} / \mathrm{CO}\right)$ in co gasification. The syngas ratio is an important factor for petrochemical manufacture by FT [17]. The syngas ratio of the product gas obtained in the gasification process was plotted in Fig 11. It was seen that the syngas ratio increased with the increase in temperature. At $600^{\circ} \mathrm{C}$ syngas ratio was 3.5 while at $700^{\circ} \mathrm{C}$ the syngas ratio was 7.6.

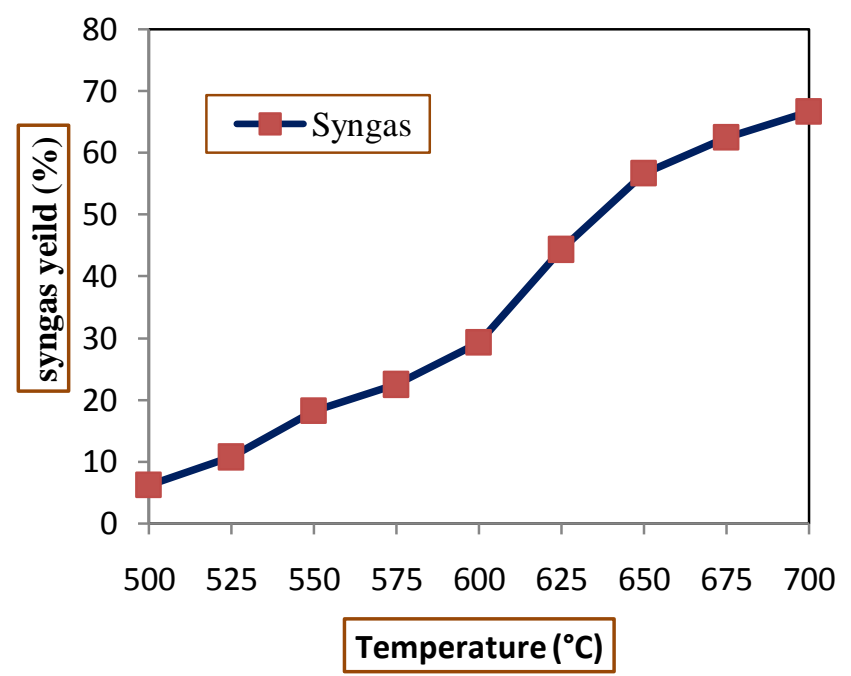

Fig -10: Syngas yield in cogasification process. 


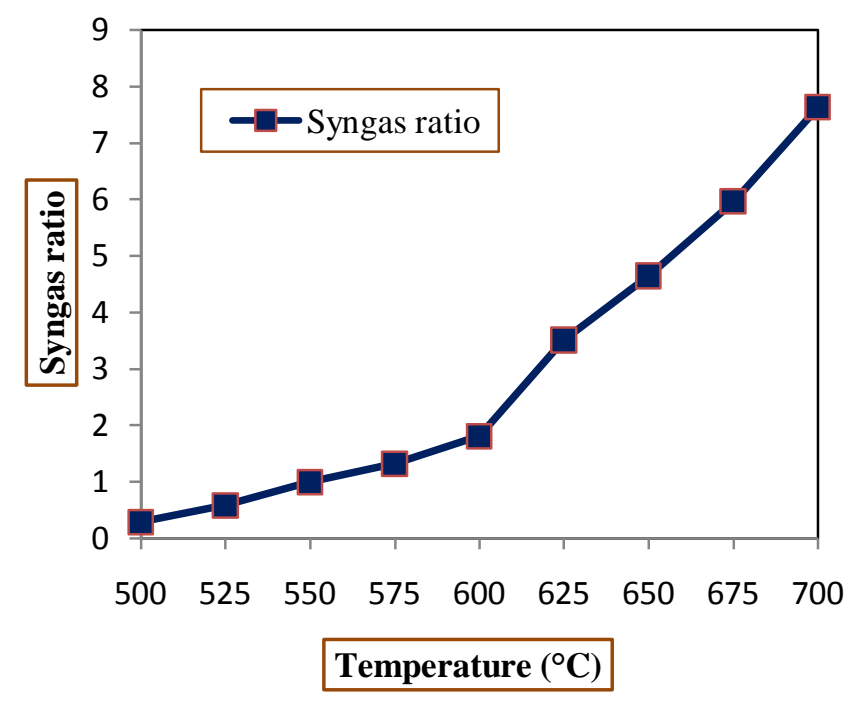

Fig -11: Syngas ratio in cogasification process.

\subsection{3 $\mathrm{CO}_{2}$ in Product Gas}

Figure 12 shows the $\mathrm{CO}_{2} \%$ in the cogasification product gas. It was observed that the $\mathrm{CO}_{2}$ production decreased with the increase in temperature. At $600^{\circ} \mathrm{C}$ the $\mathrm{CO}_{2}$ yield was $54.49 \%$ while at $700^{\circ} \mathrm{C}$ the yield was $24.59 \%$.

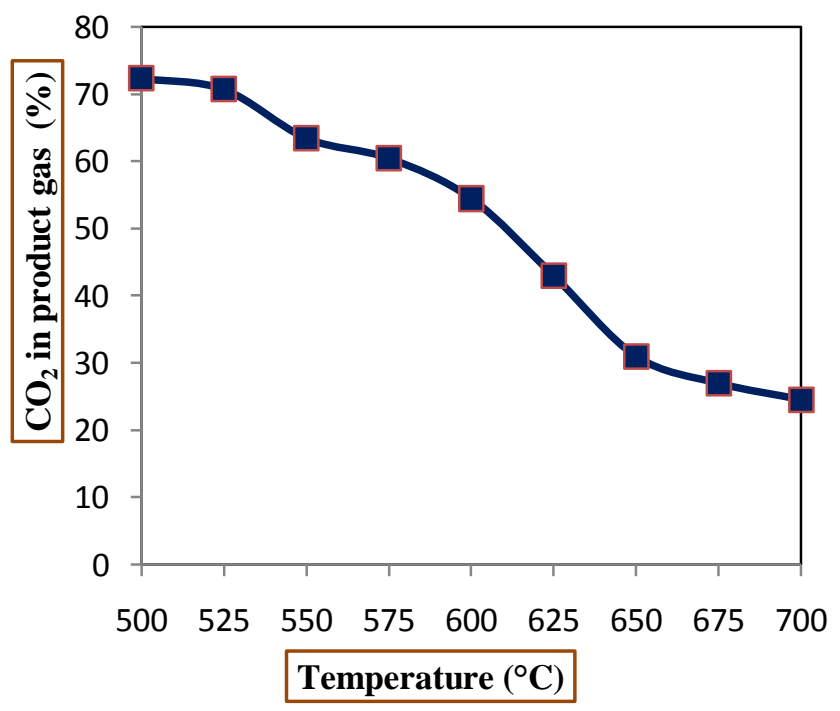

Fig -11: $\mathrm{CO}_{2}$ in product gas in cogasification process.

\section{CONCLUSION}

Thermodynamic analysis of cogasification was done to understand the effect of temperature and $\mathrm{GaCR}$ on the composition of product gas namely hydrogen, carbon monoxide, methane, $\mathrm{CO}_{2}$ and also on $\mathrm{H}_{2} \mathrm{O}(\mathrm{g})$ conversion(\%). The results show that the increase the temperature amounts to increase the hydrogen, syngas yield and syngas ratio while $\mathrm{CO}_{2}$ and methane decrease with increase the co gasification temperature. The thermoneutral temperature and HCCT were also compared. These temperatures can be used to control the process and the product gas composition in co gasification process.
In case of experimentation, the effect of temperature and constant carbon to steam ratio on $\mathrm{H}_{2}, \mathrm{CO}, \mathrm{CO}_{2}$, syngas yield and syngas ratio was observed. It showed an increase with increase the temperature in between 500 to $700^{\circ} \mathrm{C}$ while the $\mathrm{CO}_{2}$ decreased with increase the temperature. Experimentation was more kinetically controlled.

\section{REFERENCES}

[1] B.V. Reddy, "Biomass and Coal Gasification based Advanced Power Generation Systems and Recent Research Advances", Proceedings of the 37th National \& 4th International Conference on Fluid Mechanics and Fluid, p.16-18, (2010).

[2] Rodolfo Rodrigues, Nilson R. Marcilio, Jorge O. Trierweiler, "Thermodynamic Efficiency Of Gasification Of High Ash Coal And Biomass", International Conference On Coal Science \& Technology, (2011).

[3] Manzanares-Papayanopoulos, "The Co-gasification of Coal-biomass Mixtures for Power Generation: A Comparative Study for Solid Fuels Available in Mexico". Energy Sources, Part A: Recovery, Utilization, and Environmental Effects, 36(1): p. 104111, (2013).

[4] J. S. Brar, K. Singh, J.Wang, and S. Kumar, "Cogasification of Coal and Biomass: A Review", International Journal of Forestry Research, 2012, p. 10, (2012).

[5] C.C.Sreejith, C.Muraleedharan and P.Arun, "Performance prediction of steam gasification of wood using an ASPEN PLUS thermodynamic equilibrium model", International Journal of Sustainable Energy, 33, (2), p.416-434, (2014).

[6] Marı'as P. Aznar, Miguel A. Caballero, Jesu' s A. Sancho, E. France's, "Plastic waste elimination by co-gasification with coal and biomass in fluidized bed with air in pilot plant", Fuel Processing Technology ,87, p.409-420,(2006).

[7] Fermoso, Javier, Arias, Borja, Moghtaderi, Behdad, Pevida, Covadonga, Plaza, Marta G.- Rubiera, Fernando, "Effect of co-gasification of biomass and petroleum coke with coal on the production of gases", Greenhouse Gases: Science and Technology, 2,(4), p.2152-3878, (2012).

[8] Stefan Kern, Christoph Pfeifer, Hermann Hofbauer, "Synergetic Utilization of Renewable and Fossil Fuels: Dual Fluidized Bed Steam Co-gasification of Coal and Wood", APCBEE Procedia, 1, p.136-140, (2012).

[9] Co-gasification Reactivity of Coal and Woody Biomass in High-Temperature Gasification" Energy Fuels, 24 (1), p.145-151,(2010).

[10] Cormos, Calin-Cristian, Cormos, Ana-Maria, Agachi, Serban, "Power generation from coal and biomass based on integrated gasification combined cycle concept with pre- and post-combustion carbon capture methods", Asia-Pacific Journal of Chemical Engineering, 4,( 6), p.1932-2143,(2009).

[11] Jun Xie, Wenqi Zhong, Baosheng Jin, Yingjuan Shao, Hao Liu, "Simulation on gasification of 
forestry residues in fluidized beds by EulerianLagrangian approach", Bioresource Technology, 121, p. 36-46, (2012).

[12] Thanasit Wongsiriamnuay, Nattakarn Kannang, and Nakorn Tippayawong, "Effect of Operating Conditions on Catalytic Gasification of Bamboo in a Fluidized Bed", International Journal of Chemical Engineering, 2013, p.9,(2013).

[13] Catalina Rodriguez and Gerardo Gordillo, "Adiabatic Gasification and Pyrolysis of Coffee Husk Using AirSteam for Partial Oxidation", Journal of Combustion, 2011, 9,(2011).

[14] Feng Duan, Baosheng Jin , Yaji Huang, Bin Li , Yiming $\mathrm{Wu}$ and Mingyao Zhang, "Results of Bituminous Coal Gasification upon Exposure to a Pressurized Pilot-Plant Circulating Fluidized-Bed (CFB) Reactor", Energy Fuels, 24 (5), p.31503158,(2010)

[15] Xiaolin Wang, Hui Zhang, and Lili Zheng, "Novel Modeling Tool for Fixed-Bed Biomass Gasification Using High-Temperature Air",Ind. Eng. Chem. Res., 46 (26), p. 8852-8856, (2007).

[16] Kuen Song Lin, H. Paul Wang ), C.-J. Lin, Ching-I Juch, "A process development for gasification of rice husk", Fuel Processing Technology, (55) _ p.185192 (1998).

[17] Ganesh R. Kale, Bhaskar D. Kulkarni, Ranjit N. Chavan, "Combined gasification of lignite coal: Thermodynamic and application study", Journal of the Taiwan Institute of Chemical Engineers, 45, p.163-173,(2014).

[18] Di'az-Somoano M, Martı'nez-Tarazona MR. “Trace element evaporation during coal gasification based on a thermodynamic equilibrium calculation approach", Fuel, 82, p.137-45,(2003).

[19] Jukka Konttinen, Rainer Backman, M. Hupa, Antero Moilanen, Esa Kurkela, "Trace element behavior in the fluidized bed gasification of solid recovered fuels - A thermodynamic study”, Fuel,106, ,p.621631,(2013).

[20] Dong Ho Lee, Haiping Yang, Rong Yan, David Tee Liang, "Prediction of gaseous products from biomass pyrolysis through combined kinetic and thermodynamic simulations", Fuel, 86, p.410-417 (2007).

[21] Rajesh kempegowda, suttichai assabumrungrat, "Thermodynamic Analysis for Gasification of Thailand Rice Husk with Air, Steam, and Mixed Air/Steam for Hydrogen-Rich Gas Production", Intenational Journal Of Chemical Reactor Engineering, 8, p.1-25, (2010). 